\title{
Sublethal effects of tributyltin oxide on the dogwhelk Nucella lapillus
}

\author{
I. M. Davies ${ }^{1, *}$, M. J. C. Harding ${ }^{1}$, S. K. Bailey ${ }^{1}$, A. M. Shanks ${ }^{1}$, R. Länge ${ }^{2}$

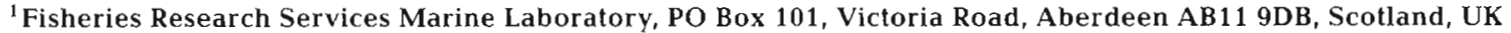 \\ ${ }^{2}$ Institute for Experimental Toxicology, Schering AG, D-13342 Berlin, Germany
}

\begin{abstract}
The sublethal effects of tributyltin oxide (TBT) at concentrations of 2 to $128 \mathrm{ng} \mathrm{l}^{-1}$ in sea water on imposex development, weight, activity and feeding rate of the adult common dogwhelk Nucella lapillus (L.) were investigated over 12 mo under conditions conforming to the UK Good Laboratory Practice standard. TBT promoted imposex development, with a no-effect concentration of $<2 \mathrm{ng}$ $1^{-1}$ for exposure of 6 mo or more. The degree of imposex did not exceed levels which caused sterility in any treatment group. Low levels of imposex in controls showed seasonal changes in intensity. Seasonal patterns were overridden by $2 \mathrm{ng} \mathrm{TBT} \mathrm{^{-1 }}$ or more. The low numbers of mortalities observed were not related to TBT concentration. The activity of dogwhelks (tendency to climb the tank walls) varied seasonally, reflecting natural behaviour patterns of wild populations. TBT exposure had no effect on this activity. The feeding rate (predation on mussels Mytilus edulis) showed marked seasonal variations in all tanks, but there was no correlation with TBT exposure. Exposure to TBT had no effect on the tissue weight of male dogwhelks, but the body weight of females was negatively correlated with TBT after 12 mo exposure. Mean bioconcentration factors (water to tissue of dogwhelks) ranged from 7400 to 25000 , and decreased with increasing TBT exposure concentration. It is estimated that the feed mussels accounted for approximately $40 \%$ of the TBT accumulated by the dogwhelks.
\end{abstract}

KEY WORDS: Nucella $\cdot$ Tributyltin $\cdot$ Effects $\cdot$ Imposex

\section{INTRODUCTION}

Laboratory and field studies (e.g. Gibbs et al. 1987, 1988, Bailey \& Davies 1989) have shown that low concentrations of tributyltin (TBT) compounds may induce development of male sexual characteristics, notably a penis and vas deferens, in female snails of the normally dioecious species Nucella lapillus (L.)

Similar and related phenomena are now known to be geographically widespread, particularly in neogastropod species. The mode of action of TBT appears to be through interference with the endocrine system (Spooner et al. 1991). In northern Europe, attention has particularly been paid to Nucella lapillus, a common member of rocky shore communities which is very sensitive to TBT contamination (Gibbs et al. 1988). Environmental monitoring programmes using $N$. lapillus have been undertaken on small (e.g. individual

\footnotetext{
•E-mail:daviesim@marlab.ac.uk
}

harbours and inletsl and large (e.g. whole North Sea) scales (Bryan et al. 1986, Bailey \& Davies 1991, Harding et al. 1992)

The limitation on the use of TBT based antifouling paints in Britain to boats over $25 \mathrm{~m}$ in length resulted in decreases in some previously high concentrations of TBT in the water to below the analytical detection limit of $3 \mathrm{ng} \mathrm{l}^{-1}$ (Dowson et al. 1993). Law et al. (1994) reported organotin concentrations within estuaries with a mean value of $6 \mathrm{ng} \mathrm{l}^{-1}$ during the period 1990 to 1992, in excess of the Environmental Quality Standard for TBT of $2 \mathrm{ng} \mathrm{l}^{-1}$ sea water set in the United Kingdom (Water Research Centre 1988). TBT can continue to enter the marine environment through leaching into the water column from sediments (Langston \& Pope 1995), and the continued use of TBT-based paints on larger vessels. Under laboratory conditions, concentrations of TBT as low as 1 to $2 \mathrm{ng} \mathrm{l}^{-1}$ resulted in the development of imposex, but with normal egg capsule production (Gibbs et al. 1988). Field measurements of TBT 
concentrations in the water at the Sullom Voe oil terminal in Shetland were in the range 3 to $7 \mathrm{ng} \mathrm{I}^{-1}$, and $100 \%$ of the female dogwhelks from the terminal area were sterile (Davies \& Bailey 1991).

While it is clear that exposure to very high concentrations of TBT can result in sterilisation and death of female dogwhelks (Gibbs et al. 1987) and subsequent reductions or elimination of wild populations (Bryan et al. 1986), the possibilities of significant sublethal effects are less well explored

The purpose of the present study was to investigate the exposure/effect relationship of TBT, in the form of TBT oxide, in dogwhelks for sublethal effects, such as imposex development, weight, mobility, and feeding rate, under controlled experimental conditions. This study conformed to the UK Good Laboratory Practice standard (GLP) (Department of Health 1989), as required by national and international regulatory authorities.

\section{MATERIALS}

The test compound, hexa-n-butyldistannoxan batch no. Beh 584 (97\% pure), was provided by Schering AG, Berlin, Germany.

Dogwhelks Nucella lapillus (L.) were collected from below mid-tide level at Firemore Bay, Loch Ewe, Wester Ross, Scotland. From the bulk collection, 4200 toothed adult snails of 25.0 to $34.7 \mathrm{~mm}$ shell length were selected for use in the experiment. The toothed condition indicates that maximum shell length has been attained. The snails appeared healthy and showed no signs of parasitic infection. The dogwhelks were fed prior to and during the exposure period on rope-grown mussels Mytilus edulis, 10 to $60 \mathrm{~mm}$ in length, initially containing $<0.02 \mathrm{mg}$ TBT $\mathrm{kg}^{-1}$ (wet weight). Prior to exposure, the dogwhelks contained $<0.02 \mathrm{mg} \mathrm{TBT} \mathrm{kg}^{-1}$ (wet weight) and had a low level of imposex [incidence of imposex 12\%, Relative Penis Size Index (RPSI) $0.01 \%$, Vas Deferens Sequence Index (VDSI) 0.34]. See 'Methods' for further definition.

Additional dogwhelks were collected from the natural environment on sampling occasions to enable comparison of seasonal effects under laboratory conditions with those observed in the natural populations.

\section{METHODS}

Experimental system and husbandry. Snails were acclimated in a large holding tank with a flow through of clean sea water (TBT $<1.5 \mathrm{ng} \mathrm{l}^{-1}$ ). Exposures were carried out in 6 large fibreglass tanks with a flowthrough system. Tanks 1 and 2 were used as dilution water and carrier solvent controls respectively $(<1.5 \mathrm{ng}$ TBT $~^{-1}$ ). The remaining tanks (3 to 6 ) were treated with TBT at nominal concentrations of $2,8,32$ and

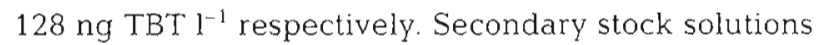
containing the test substance were continuously pumped $\left(0.1 \mathrm{mI} \mathrm{min}^{-1}\right)$ into the dilution water inflow (1500 $\mathrm{ml} \mathrm{min}^{-1}$ ) to each tank. Ethanol was used as a carrier solvent to facilitate mixing between the dilution water and the test substance. The 2 control tanks, 1 with sea water alone and 1 with sea water and ethanol (the carrier control), each held 800 dogwhelks, and the 4 treatment tanks 600 dogwhelks each.

The snails were maintained under simulated tidal conditions, whereby the tanks were completely emptied of the contents of $400 \mathrm{l}$ through $2.5 \mathrm{~cm}$ electrically activated ball valves every $12 \mathrm{~h}$. The tanks were refilled at a rate of $1.5 \mathrm{l} \mathrm{min} \mathrm{m}^{-1}$, thus allowing a period of 'low water'. Algal growth and debris were removed from the experimental tanks and feed trays twice each week during normal tank drainage.

The experiment ran continuously for $52 \mathrm{wk}$. Water temperature, $\mathrm{pH}$, dissolved oxygen concentration and salinity were measured daily for the first $3 \mathrm{mo}$ of the test. Acceptable limits for routine environmental parameters were defined at the beginning of the experiment to reflect normal conditions under which dogwhelks may be found in the UK. The limits were $\mathrm{pH} 7.5$ to $8.5, \mathrm{DO}$ (dissolved oxygen) $>60 \%$ saturation, temperature $<25^{\circ} \mathrm{C}$. The results for these parameters showed low variability and consequently the frequency of measurement was decreased to twice weekly for the remainder of the experiment. The dilution water flow rate and dosing solution flow rate were checked daily.

New feed mussels were collected approximately monthly and were maintained in mesh bags suspended in clean (TBT $<1.5 \mathrm{ng} \mathrm{l}^{-1}$ ) sea water. Feed mussels were removed from the test tanks approximately every $2 \mathrm{wk}$ and about $2 \mathrm{~kg}$ of new mussels added to each tank. The dogwhelks fed freely and mussels were available to excess. The mussels fed on natural particulate material in the incoming sea water and appeared healthy at all times.

Chemical analysis. Water samples from the control and treatment tanks were taken once each week prior to replacement of the secondary stocks and analysed for TBT by solvent extraction and graphite furnace AAS (atomic absorption spectrometry) using a modification (Bailey 1991) of the method of McKie (1987) with a detection limit of $1.5 \mathrm{ng} \mathrm{l}^{-1}$ (2 standard deviations of repeated analysis of standards at $5 \mathrm{ng} \mathrm{l}^{-1}$ ).

The secondary stock concentrations were reviewed weekly following analyses of the water samples and adjustments made where necessary to maintain the target concentrations of TBT in each tank. 
TBT concentrations in dogwhelk and mussel tissue samples were determined following McKie (1987). The limit of detection was $0.02 \mathrm{mg} \mathrm{kg}^{-1}$ (2 standard deviations of repeated analysis of samples containing $200 \mathrm{ng}$ of tin) and the results are expressed in wet tissue weight.

Sampling and imposex determination. The RPSI, which is the mean bulk of the female penis (length ${ }^{3}$ ) expressed as a percentage of the mean bulk of the male penis (length ${ }^{3}$ ) in a sample, and the VDSI (Gibbs et al. 1987), an index for the individual stage (Bryan et al. 1986) of the development of a vas deferens in the female, were determined as described by Gibbs et al. (1987). In addition, the incidence of imposex (the percentage of females in a sample that show signs of both penis development and vas deferens development at VDSI Stage 2 or above) was recorded. Samples of snails were removed from the beach and each tank at 3 mo (100 dogwhelks), 6 mo (200 dogwhelks), 9 mo (100 dogwhelks) and 12 mo (all remaining dogwhelks, 174 to 367 individuals). On each sampling occasion, sub-samples of 20 males and 20 females from each treatment tank were bulked, homogenised and analysed for TBT after removal of the operculae.

Estimation of weight. The condition of the soft parts of the test dogwhelks was estimated by determining the mean wet tissue weight of both male and female snails at each quarterly sampling period. Three samples of 10 individuals of each sex were dissected out of the shells and weighed at each sampling occasion.

Measurement of activity. Snails in the tanks tended to climb the tank walls and accumulate at the water's surface. To ensure that all were exposed to the test substance the snails were periodically dislodged and returned to the base of the tanks during routine tank maintenance. Activity of the snails was estimated by counting the number of individuals that had ascended the tank walls to within $20 \mathrm{~cm}$ of the water surface, 20 to $24 \mathrm{~h}$ following dislodgement. Observations were made 2 to 3 times per week from January to August.

Estimation of food consumption rates. The quantity of mussels eaten by the snails during each feeding period was estimated by 2 methods. In both cases, uneaten feed mussels were recovered from the tank and weighed. The weight of soft parts consumed was calculated by either (Method 1) treating inter-valvular fluid as a component of the soft tissue, or (Method 2) omitting the inter-valvular fluid.

TBT accumulation in feed mussels. The dogwhelks were exposed to TBT both directly through the water and from TBT accumulated by the feed mussels. The weekly measurements of TBT concentrations in the water would quantify exposure through the former route. It was likely, however, that concentrations of
TBT in the feed mussels would vary according to the length of time that the mussels were in the treatment tanks. Mussels ingested at the start of a new feed period, for example, would be expected to contain less TBT than those that had been exposed to TBT for $2 \mathrm{wk}$. During November, and May and August the following year, the accumulation of TBT in the feed mussels was investigated. Samples of 5 mussels were removed from each tank at $3 \mathrm{~d}$ intervals for $2 \mathrm{wk}$ in November and August, and the soft parts homogenised and analysed for TBT In May 5 mussels were sampled after $15 \mathrm{~d}$ exposure

\section{RESULTS}

\section{Experimental system}

All routine environmental parameters monitored remained well within the acceptable limits outlined above. Mean values were $\mathrm{pH} 8.09$, DO $95 \%$ saturation, salinity $33.9 \mathrm{psu}$, and the temperature range 5.9 to $14.2^{\circ} \mathrm{C}$. There were no significant differences among tanks

Mean concentrations of TBT in water from each tank (Table 1) were close to the target concentrations of 2,8 , 32 and $128 \mathrm{ng} \mathrm{l}^{-1}$. All results and statistical calculations used the nominal values.

As imposex analysis takes no account of the overall size of an individual, it was necessary to examine the size, in terms of shell length, of the individuals allocated to each experimental tank and taken from the beach. Fig. 1 summarises these shell length distributions in terms of box-and-whisker plots (Tukey 1977) and shows that there is considerable overlap. The sample of females taken from the beach at 9 mo includes 2 particularly large individuals (39.5 and $39.8 \mathrm{~mm}$ ) and including them gives a mean shell length of $31.3 \mathrm{~mm}$ with a standard error of \pm 0.405 while excluding them reduces the mean to $30.9 \mathrm{~mm}$ with a standard error of \pm 0.324 .

Table 1. Summary of water analysis results (ng TBT ${ }^{-1}$ ). Water concentrations below the detection limit were omitted in calculating the mean and median concentrations. In cases where this has occurred, the mean and median are recorded as 'less than' a particular value

\begin{tabular}{|ccccc|}
\hline Tank & Target conc. & Meanconc. & Median & SE \\
\hline 1 & $<1.5$ & $<1.5$ & $<1.5$ & - \\
2 & $<1.5$ & $<1.5$ & $<1.5$ & - \\
3 & 2 & $<2.67$ & $<2.15$ & 0.24 \\
4 & 8 & 7.74 & 7.24 & 0.38 \\
5 & 32 & 33.42 & 32.04 & 1.65 \\
6 & 128 & 124.59 & 120.83 & 5.83 \\
\hline
\end{tabular}




\section{Males}

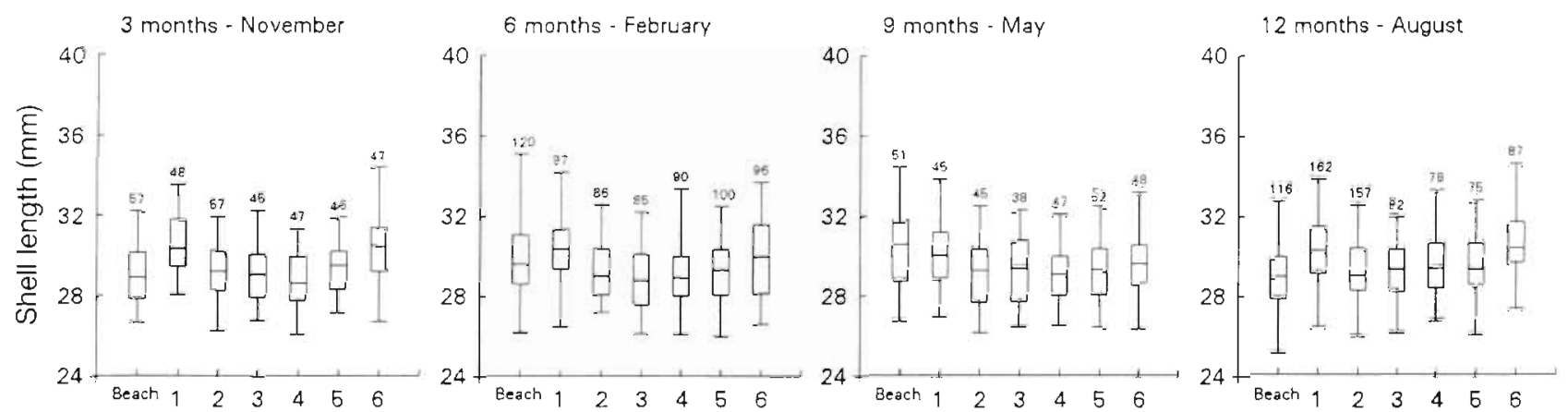

\section{Females}
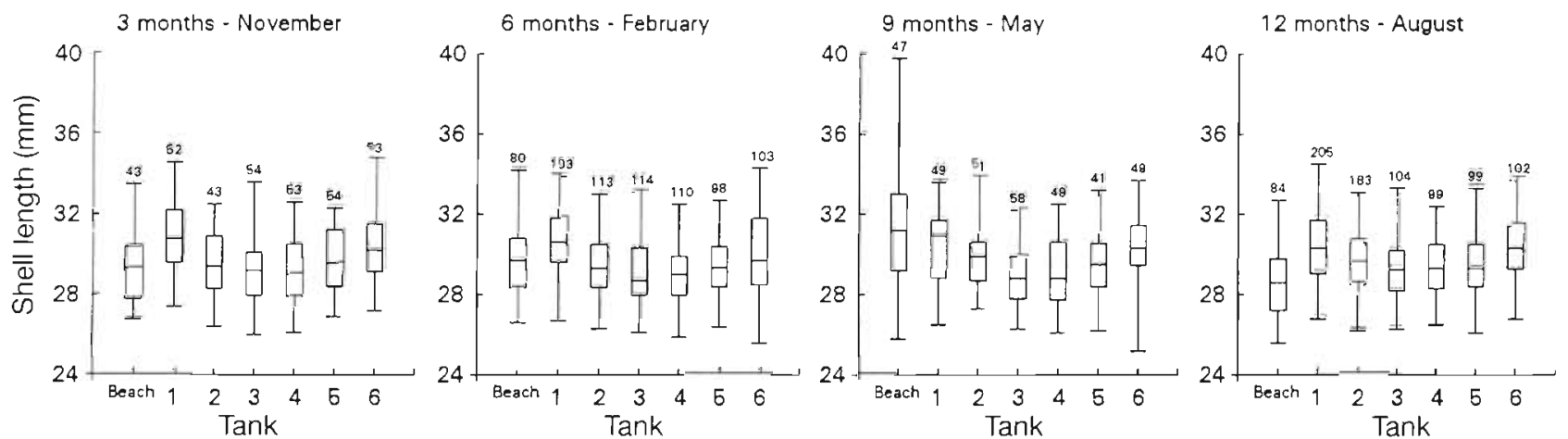

Fig. I Nucella lapillus. Box-and-whisker plots of the shell lengths and numbers of individuals in the samples of dogwhelks from each treatment tank and a beach sample on each sampling occasion. Tank 1. sea water control; Tank 2: carrier control;

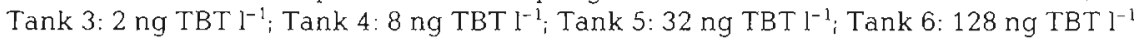

An analysis of variance of mean shell length (Table 2) indicated significant differences between tanks ( $\mathrm{p}<0.001$ ) but not between the sexes or between sampling times. The mean shell length of both males

Table 2. Nucella lapillus. Mean and standard deviation of shell lengths measured on each sampling occasion

\begin{tabular}{|c|c|c|c|c|c|c|c|c|}
\hline Treatment & \multicolumn{2}{|c|}{$\begin{array}{l}3 \text { mo, Nov } \\
\text { Mean SD }\end{array}$} & \multicolumn{2}{|c|}{$6 \mathrm{mo}, \mathrm{Feb}$} & \multicolumn{2}{|c|}{9 mo, May } & \multicolumn{2}{|c|}{$\begin{array}{l}12 \text { mo, Aug } \\
\text { Mean SD }\end{array}$} \\
\hline \multicolumn{9}{|l|}{ Males } \\
\hline Beach & 29.1 & 1.46 & 29.8 & 1.66 & 30.4 & 1.69 & 28.9 & 1.48 \\
\hline Control & 30.6 & 1.36 & 30.4 & 1.46 & 30.1 & 1.65 & 30.3 & 1.58 \\
\hline Carnier control & 29.3 & 1.31 & 29.3 & 1.46 & 29.1 & 1.57 & 29.2 & 1.40 \\
\hline $2 \mathrm{ng} \mathrm{TBT} \mathrm{I}{ }^{-1}$ & 29.8 & 1.43 & 28.9 & 1.50 & 29.3 & 1.75 & 29.4 & 1.41 \\
\hline $8 \mathrm{ng} \mathrm{TBT} \mathrm{l}^{-1}$ & 28.9 & 1.39 & 29.0 & 1.50 & 29.0 & 1.40 & 29.5 & 1.36 \\
\hline $32 \mathrm{ng} \mathrm{TBT}^{-1}$ & 29.5 & 1.27 & 29.3 & 1.40 & 29.2 & 1.58 & 29.5 & 1.49 \\
\hline $128 \mathrm{ng} \mathrm{TBT} \mathrm{l}^{-1}$ & 30.5 & 1.63 & 29.9 & 1.86 & 29.5 & 1.51 & 30.5 & 1.60 \\
\hline \multicolumn{9}{|l|}{ Females } \\
\hline Beach & 29.5 & 1.82 & 29.8 & 1.74 & 30.9 & 2.17 & 28.5 & 1.60 \\
\hline Control & 30.9 & 1.70 & 30.5 & 1.70 & 30.5 & 1.77 & 30.5 & 1.72 \\
\hline Carrier control & 29.6 & 1.62 & 29.4 & 1.44 & 29.8 & 1.49 & 29.6 & 1.40 \\
\hline $2 \mathrm{ng} \mathrm{TBT} 1^{-1}$ & 29.2 & 1.61 & 29.1 & 1.49 & 28.9 & 1.40 & 29.3 & 1.44 \\
\hline $8 \mathrm{ng} \mathrm{TBT} \mathrm{l^{-1 }}$ & 29.2 & 1.53 & 29.0 & 1.41 & 29.1 & 1.56 & 29.4 & 1.40 \\
\hline 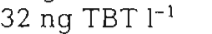 & 29.7 & 1.50 & 29.4 & 1.39 & 29.5 & 1.67 & 29.5 & 1.43 \\
\hline $128{\mathrm{ng} \mathrm{TBT} l^{-1}}^{-1}$ & 30.3 & 1.68 & 30.0 & 1.95 & 30.3 & 165 & 30.3 & 1.54 \\
\hline
\end{tabular}

and females in Tanks 1 and 6 was higher than in the other 4 tanks on all sampling occasions. However, the beach samples of both males and females gave the highest mean shell length at 9 mo (i.e. May). Although statistically significant differences have been identified between mean shell lengths, the largest difference between experimental tanks was $2 \mathrm{~mm}$ (Table 2).

The relationship between penis length and shell length in all 56 samples (both sexes for 6 tanks and a beach sample on 4 sampling occasions) was examined further. No significant relationship was found in 23 of the 28 cases for females or in 17 of the 28 cases for males. In 3 of the 5 cases where significance was found for females, the relationship became non-significant when a single influential value was removed. In the case of the males, 7 of the 11 significant relationships fell into this category. For the 2 remaining female and 4 remaining 
Table 3. Nucella lapillus. Incidence of imposex and shell length in female snails from Tank 2 (carrier control) at 6 mo and Tank 3 ( $2 \mathrm{ng} \mathrm{TBT} \mathrm{r}^{-1}$ ) at 9 mo exposure

\begin{tabular}{|c|c|c|c|c|c|c|}
\hline $\begin{array}{l}\text { Shell } \\
\text { length }\end{array}$ & $\begin{array}{c}\text { No. of } \\
\text { females }\end{array}$ & $\begin{array}{l}\text { Tank } 2 \text { at } 6 \text { mo } \\
\text { No. of females at VDSI } \\
\text { Stage } 2 \text { and above }\end{array}$ & $\begin{array}{c}\% / \% \\
\text { incidence }\end{array}$ & $\begin{array}{c}\text { No. of } \\
\text { females }\end{array}$ & $\begin{array}{l}\text { Tank } 3 \text { at } 9 \text { mo } \\
\text { No. of females at VDSI } \\
\text { Stage } 2 \text { and above }\end{array}$ & $\begin{array}{c}\% \\
\text { incidence }\end{array}$ \\
\hline $26.1-27.0$ & 6 & 3 & 50 & 7 & 5 & 71 \\
\hline $27.1-28.0$ & 16 & 6 & 38 & 14 & 9 & 64 \\
\hline $28.1-29.0$ & 21 & 7 & 33 & 11 & 9 & 82 \\
\hline $29.1-30.0$ & 32 & 13 & 41 & 14 & 10 & 71 \\
\hline $30.1-31.0$ & 20 & 7 & 35 & 9 & 8 & 89 \\
\hline $31.1-32.0$ & 14 & 5 & 36 & $2^{d}$ & $2^{a}$ & $100^{a}$ \\
\hline $32.1-33.0$ & 4 & 2 & 50 & $1^{\text {a }}$ & $1^{a}$ & $100^{\circ}$ \\
\hline
\end{tabular}

male datasets, there is no well defined relationship. over $80 \%$ of the variability in penis length being unaccounted for by variability in shell length in all 6 cases. Over the narrow size range of snails used in this experiment, penis length is independent of shell length.

The relation between prevalence of imposex and shell length was investigated in 2 typical data sets, Tank 2 at 6 mo and Tank 3 at 9 mo (Table 3). In both cases, over the size range of snails used in the experiment, there was no linear relationship between them; large individuals (>30 mm) showed imposex development similar to that of smaller ones (e.g. Tank 2, 6 mo, incidence of occurrence in individuals $\leq 30 \mathrm{~mm}=39 \%$, in individuals $>30 \mathrm{~mm}=37 \%$ ).

\section{Effects of TBT on dogwhelks}

\section{Mortalities}

The overall mortality in this experiment was less than $10 \%$ in all tanks, based on the initial number of snails in the tanks. The highest number of mortalities occurred in the 2 control tanks (Tank $1=6.2 \%$, Tank $2=8.8 \%$ ) and the least number of deaths occurred in Tank $6(2.6 \%)$. The mortalities for Tanks 3, 4 and 5 were $3.4,3.7 \%$ and $3.3 \%$ respectively. A chi-squared test of the independence of mortality and tank indicated significant differences in mortality between tanks (chi-squared $=35.89, \mathrm{df}=5, \mathrm{p}<0.001$ ) . Most of this significance resulted from the difference between Tank 2 and the other 5 tanks. There is therefore no clear relationship between treatment dose and the number of mortalities
Table 4. Nucella lapillus. TBT concentrations in dogwhelks ( $\mathrm{mg} \mathrm{kg}^{-1}$ wet weight) from each sampling occasion

\begin{tabular}{|c|c|c|c|c|c|}
\hline $\begin{array}{l}\text { Treatment } \\
\text { conc. }\left(\mathrm{ng} \mathrm{l}^{-1}\right)\end{array}$ & Sex & 3 mo, Nov & $6 \mathrm{mo}$. Feb & 9 mo, May & $12 \mathrm{mo}$, Aug \\
\hline Beach & $\begin{array}{l}\text { Female } \\
\text { Male } \\
\text { Mean' }\end{array}$ & $\begin{array}{l}<0.02 \\
<0.02 \\
<0.02\end{array}$ & $\begin{array}{l}<0.02 \\
<0.02 \\
<0.02\end{array}$ & $\begin{array}{l}<0.02 \\
<0.02 \\
<0.02\end{array}$ & $\begin{array}{l}<0.02 \\
<0.02 \\
<0.02\end{array}$ \\
\hline Control & $\begin{array}{l}\text { Female } \\
\text { Male } \\
\text { Mean }\end{array}$ & $\begin{array}{l}<0.02 \\
<0.02 \\
<0.02\end{array}$ & $\begin{array}{l}<0.02 \\
<0.02 \\
<0.02\end{array}$ & $\begin{array}{l}<0.02 \\
<0.02 \\
<0.02\end{array}$ & $\begin{array}{l}<0.02 \\
<0.02 \\
<0.02\end{array}$ \\
\hline Carrier control & $\begin{array}{l}\text { Female } \\
\text { Male } \\
\text { Mean }\end{array}$ & $\begin{array}{l}<0.02 \\
<0.02 \\
<0.02\end{array}$ & $\begin{array}{l}<0.02 \\
<0.02 \\
<0.02\end{array}$ & $\begin{array}{l}<0.02 \\
<0.02 \\
<0.02\end{array}$ & $\begin{array}{l}<0.02 \\
<0.02 \\
<0.02\end{array}$ \\
\hline 2 & $\begin{array}{l}\text { Female } \\
\text { Male } \\
\text { Mean }\end{array}$ & $\begin{array}{r}0.03 \\
<0.02 \\
<0.03\end{array}$ & $\begin{array}{r}0.04 \\
<0.02 \\
<0.03\end{array}$ & $\begin{array}{l}0.07 \\
0.06 \\
0.07\end{array}$ & $\begin{array}{l}0.07 \\
0.06 \\
0.07\end{array}$ \\
\hline 8 & $\begin{array}{l}\text { Female } \\
\text { Male } \\
\text { Mean }\end{array}$ & $\begin{array}{l}0.14 \\
0.14 \\
0.14\end{array}$ & $\begin{array}{l}0.14 \\
0.09 \\
0.12\end{array}$ & $\begin{array}{l}0.21 \\
0.21 \\
0.21\end{array}$ & $\begin{array}{l}0.21 \\
0.23 \\
0.22\end{array}$ \\
\hline 32 & $\begin{array}{l}\text { Female } \\
\text { Male } \\
\text { Mean }\end{array}$ & $\begin{array}{l}0.46 \\
0.54 \\
0.50\end{array}$ & $\begin{array}{l}0.57 \\
0.56 \\
0.57\end{array}$ & $\begin{array}{l}0.56 \\
0.57 \\
0.57\end{array}$ & $\begin{array}{l}0.69 \\
0.53 \\
0.61\end{array}$ \\
\hline 128 & $\begin{array}{l}\text { Female } \\
\text { Male } \\
\text { Mean }\end{array}$ & $\begin{array}{l}1.01 \\
1.04 \\
1.03\end{array}$ & $\begin{array}{l}0.74 \\
1.00 \\
0.87\end{array}$ & $\begin{array}{l}0.97 \\
0.91 \\
0.94\end{array}$ & $\begin{array}{l}1.04 \\
0.89 \\
0.97\end{array}$ \\
\hline
\end{tabular}


Table 5. Nucella lapillus. Imposex measurements (incidence of imposex, RPSI and VDSI) in dogwhelks from all sampling occasions

\begin{tabular}{|c|c|c|c|c|c|c|c|c|c|c|c|c|c|c|c|}
\hline \multirow{2}{*}{$\begin{array}{l}\text { Time of } \\
\text { sampling } \\
\text { Source }\end{array}$} & \multicolumn{4}{|c|}{ Penis length (mm) } & \multirow{2}{*}{$\begin{array}{l}\text { No. of } \\
\text { females }\end{array}$} & \multirow{2}{*}{$\begin{array}{l}\text { Incidence } \\
\text { of impo- } \\
\text { sex }(\%)\end{array}$} & \multirow{2}{*}{$\begin{array}{c}\text { RPSI } \\
(\%)\end{array}$} & \multirow[t]{2}{*}{ VDSI } & \multicolumn{7}{|c|}{ Percentage of females at VDSI-Stage: } \\
\hline & \multicolumn{2}{|c|}{ Male } & Female & $\mathrm{SD}$ & & & & & 0 & 1 & 2 & 3 & 4 & 5 & 6 \\
\hline Pre-experiment & & & & & & & & & & & & & & & \\
\hline Beach & 3.76 & 0.41 & 0.16 & 0.28 & 107 & 12 & 0.01 & 0.34 & 82.2 & 5.6 & 6.5 & 3.7 & 1.9 & 0 & 0 \\
\hline $3 \mathrm{mo}, \mathrm{Nov}$ & & & & & & & & & & & & & & & \\
\hline Beach & 3.55 & 0.43 & 0.14 & 0.27 & 43 & 23 & 0.01 & 0.65 & 67.4 & 9.3 & 16.3 & 4.7 & 2.3 & 0 & 0 \\
\hline 1 (control) & 3.59 & 0.39 & 0.21 & 0.30 & 52 & 21 & 0.02 & 0.71 & 73.1 & 5.8 & 3.8 & 11.5 & 5.8 & 0 & 0 \\
\hline 2 (car control) & 3.60 & 0.43 & 0.19 & 0.32 & 43 & 16 & 0.01 & 0.58 & 65.1 & 18.6 & 9.3 & 7.0 & 0 & 0 & 0 \\
\hline $3\left(2 \mathrm{ng} \mathrm{l}^{-1}\right)$ & 3.60 & 0.45 & 0.25 & 0.43 & 53 & 33 & 0.03 & 1.04 & 50.9 & 15.1 & 15.1 & 17.0 & 1.9 & 0 & 0 \\
\hline $4\left(8 \mathrm{ng} \mathrm{l}^{-1}\right)$ & 3.51 & 0.36 & 0.65 & 0.81 & 51 & 53 & 0.64 & 1.69 & 27.5 & 17.6 & 21.6 & 21.6 & 11.8 & 0 & 0 \\
\hline $5\left(32 \mathrm{ng} \mathrm{l}^{-1}\right)$ & 3.68 & 0.33 & 0.97 & 0.77 & 54 & 96 & 1.83 & 3.31 & 0 & 3.7 & 13.0 & 31.5 & 51.9 & 0 & 0 \\
\hline $6\left(128 \mathrm{ng} \mathrm{J}^{-1}\right)$ & 3.79 & 0.41 & 1.92 & 1.03 & 52 & 98 & 13.00 & 3.87 & 0 & 0 & 1.9 & 9.6 & 88.5 & 0 & 0 \\
\hline $6 \mathrm{mo}$, Feb & & & & & & & & & & & & & & & \\
\hline Beach & 3.79 & 0.37 & 0.39 & 0.39 & 80 & 53 & 0.11 & 1.60 & 28.8 & 18.8 & 22.5 & 23.8 & 6.3 & 0 & 0 \\
\hline 1 (control) & 3.71 & 0.38 & 0.42 & 0.58 & 103 & 44 & 0.15 & 1.32 & 41.7 & 14.6 & 18.4 & 20.4 & 4.9 & 0 & 0 \\
\hline 2 (car. control) & 3.71 & 0.39 & 0.29 & 0.43 & 114 & 38 & 0.05 & 1.11 & 45.6 & 16.7 & 21.1 & 14.0 & 2.6 & 0 & 0 \\
\hline $3\left(2 \mathrm{ng} \mathrm{l}^{-1}\right)$ & 3.60 & 0.36 & 0.67 & 0.77 & 113 & 68 & 0.64 & 2.04 & 9.7 & 21.2 & 36.3 & 20.4 & 12.4 & 0 & 0 \\
\hline $4\left(8 \mathrm{ng} \mathrm{l}^{-1}\right)$ & 3.68 & 0.38 & 1.01 & 0.85 & 110 & 86 & 2.07 & 2.91 & 0.1 & 12.7 & 19.1 & 29.1 & 38.2 & 0 & 0 \\
\hline $5\left(32 \mathrm{ng} \mathrm{l}^{-1}\right)$ & 3.70 & 0.35 & 2.05 & 0.90 & 96 & 99 & 17.01 & 3.92 & 0 & 1.0 & 0 & 5.2 & 92.7 & 0.1 & 0 \\
\hline $6\left(128 \mathrm{ng} \mathrm{l}^{-1}\right)$ & 3.82 & 0.40 & 2.90 & 0.72 & 103 & 100 & 43.75 & 4.11 & 0 & 0 & 0 & 0 & 89.3 & 10.7 & 0 \\
\hline 9 mo, May & & & & & & & & & & & & & & & \\
\hline Beach & 3.90 & 0.41 & 0.35 & 0.37 & 48 & 70 & 0.07 & 1.92 & 14.6 & 16.7 & 37.5 & 25.0 & 6.3 & 0 & 0 \\
\hline 1 (control) & 3.81 & 0.53 & 0.42 & 0.71 & 50 & 48 & 0.13 & 1.56 & 28.0 & 24.0 & 16.0 & 28.0 & 4.0 & 0 & 0 \\
\hline 2 (car. control) & 3.73 & 0.55 & 0.26 & 0.45 & 50 & 37 & 0.03 & 1.32 & 28.0 & 34.0 & 18.0 & 18.0 & 2.0 & 0 & 0 \\
\hline $3\left(2 \mathrm{ng} \mathrm{l}^{-1}\right)$ & 3.71 & 0.40 & 0.72 & 0.83 & 58 & 76 & 0.73 & 2.36 & 5.1 & 19.0 & 27.6 & 31.0 & 17.2 & 0 & 0 \\
\hline $4(8 \mathrm{ng} l)$ & 3.72 & 0.47 & 1.55 & 0.98 & 48 & 96 & 7.23 & 3.50 & 0 & 2.1 & 12.5 & 18.8 & 66.7 & 0 & 0 \\
\hline $5\left(32 \mathrm{ng} \mathrm{l}^{-1}\right)$ & 3.73 & 0.39 & 2.40 & 0.89 & 39 & 93 & 26.64 & 3.87 & 0 & 2.6 & 2.6 & 0 & 94.8 & 0 & 0 \\
\hline $6\left(128 \mathrm{ng} \mathrm{l}^{-1}\right)$ & 3.84 & 0.33 & 3.04 & 0.61 & 49 & 100 & 49.62 & 4.00 & 0 & 0 & 0 & 2.0 & 96.0 & 2.0 & 0 \\
\hline $12 \mathrm{mo}$, Aug & & & & & & & & & & & & & & & \\
\hline Beach & 3.33 & 0.35 & 0.14 & 0.23 & 84 & 26 & 0.01 & 0.81 & 60.7 & 13.1 & 13.1 & 10.7 & 2.4 & 0 & 0 \\
\hline 1 (control) & 3.31 & 0.41 & 0.33 & 0.46 & 205 & 37 & 0.10 & 1.06 & 52.2 & 10.7 & 20.0 & 13.2 & 3.9 & 0 & 0 \\
\hline 2 (car. control) & 3.30 & 0.40 & 0.24 & 0.45 & 181 & 24 & 0.04 & 0.70 & 64.1 & 11.6 & 14.9 & 9.4 & 0 & 0 & 0 \\
\hline $3\left(2 \mathrm{ng} \mathrm{l}^{-1}\right)$ & 3.56 & 0.33 & 1.34 & 0.89 & 104 & 92 & 5.33 & 3.15 & 0 & 7.7 & 12.5 & 36.5 & 43.3 & 0 & 0 \\
\hline 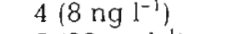 & 3.66 & 0.37 & 2.17 & 0.76 & 99 & 100 & 20.84 & 3.97 & 0 & 0 & 0 & 6.1 & 90.9 & 3.0 & 0 \\
\hline $5\left(32 \mathrm{ng} \mathrm{l}^{-1}\right)$ & 3.83 & 0.35 & 2.87 & 0.51 & 98 & 99 & 42.08 & 4.33 & 0 & 0 & 0 & 0 & 67.3 & 32.7 & 0 \\
\hline $6\left(128 \mathrm{ng}^{-1}\right)$ & 3.69 & 0.38 & 3.17 & 0.49 & 102 & 100 & 63.40 & 4.25 & 0 & 0 & 0 & 0 & 75.5 & 24.5 & 0 \\
\hline
\end{tabular}

Tanks 3 to 6 over the 12 mo of the experiment increased with the treatment concentration, being $<0.05$, $0.17,0.56$ and $0.95 \mathrm{mg} \mathrm{kg}^{-1}$ respectively.

\section{Penis length in males and females}

Penis length distributions in male and female dogwhelks from each tank and the beach on each sampling occasion are shown in Table 5, presented graphically as box-and-whisker plots in Fig. 2 and summarised in Fig. 3.

A 2-way analysis of variance of mean penis length in males (Table 5) indicated significant differences between sampling occasions $(p<0.01)$ but not between tanks. At 12 mo the overall mean penis length was smaller $(3.53 \mathrm{~mm})$ than at the other 3 sampling times $(3.62,3.72$ and $3.78 \mathrm{~mm}$, respectively). The standard error of the difference between 2 sampling time means is \pm 0.064 . This results from the mean penis length of the males from the beach and in the control tanks at
12 mo $(3.33,3.31$ and $3.30 \mathrm{~mm}$ respectively) being less than in the tanks dosed with TBT $(3.56,3.66,3.83$ and $3.69 \mathrm{~mm}$ for increasing dose respectively). The decrease in male penis length shown in the beach and control tanks at 12 mo was absent from the animals exposed to $2 \mathrm{ng} \mathrm{TBT} \mathrm{l}^{-1}$ or above (Fig. 3).

Fig. 2 shows clearly the differences in penis length in females at the 4 sampling times resulting from different treatments, and a 2-way analysis of variance of mean penis length confirmed significant differences between sampling occasions $(p<0.01)$ and between treatments $(p<0.001)$. The standard error of the difference of 2 sampling time means was \pm 0.189 and of the treatment means was \pm 0.250 . The size of the female penis increased with concentration of TBT and the length of exposure (Fig. 3).

In November fewer than half the sampled females from the beach, both control tanks and the lowest dosed tank (Tank 3: $2 \mathrm{ng} \mathrm{l}^{-1}$ ) displayed a penis. More than $50 \%$ of the females from the beach and in control 

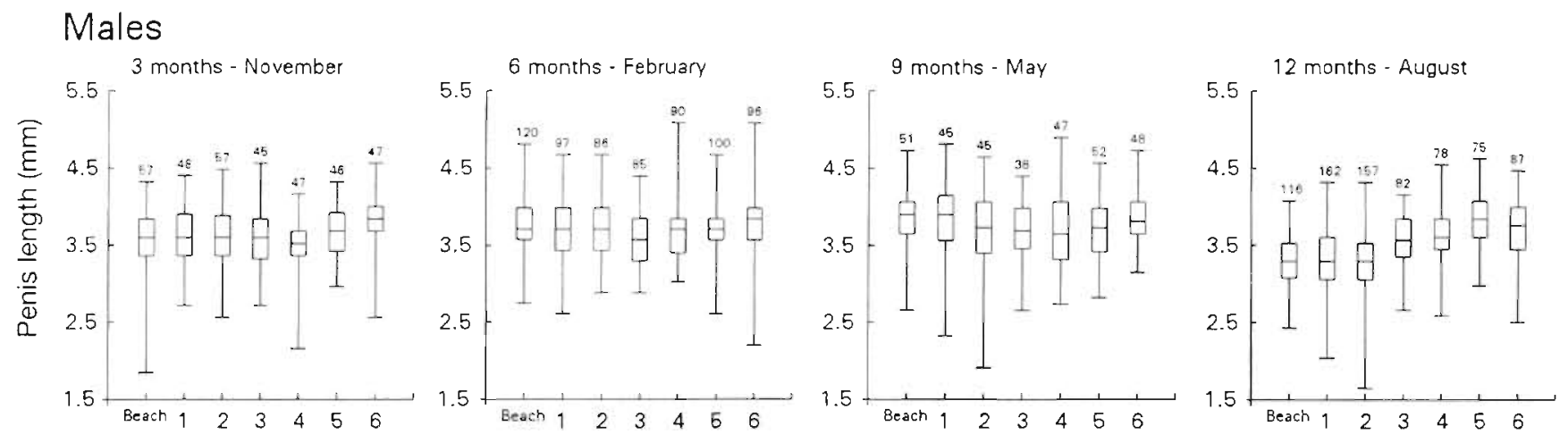

\section{Females}
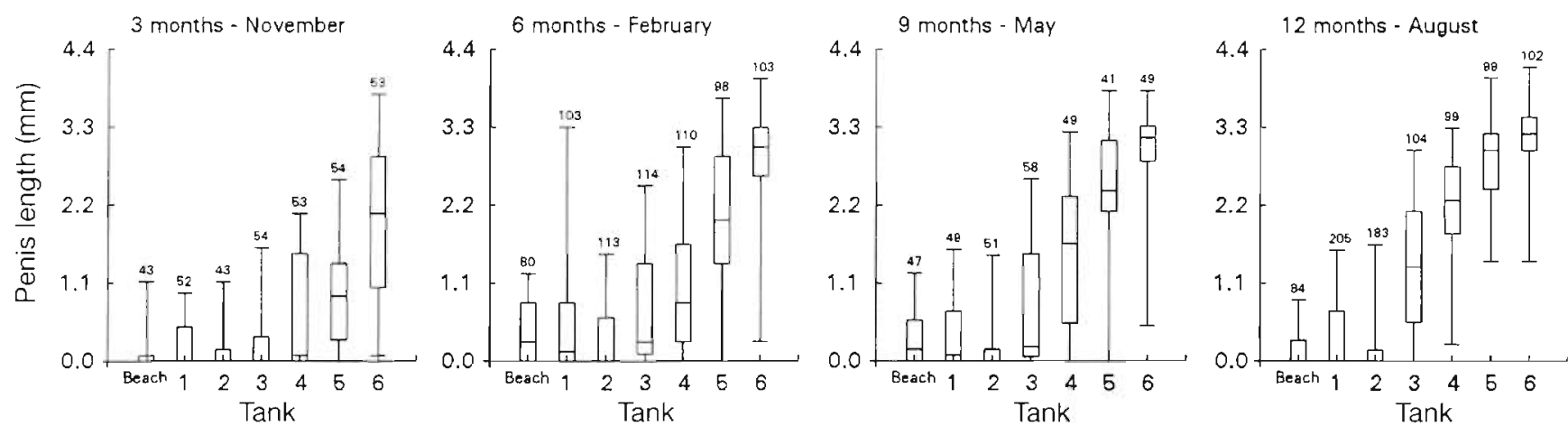

Fig. 2. Nucella lapillus. Box-and-whisker plots of the penis lengths and numbers of undividuals in the samples of dogwhelks from each treatment tank and a beach sample on each sampling occasion. Tank 1. sea water control; Tank 2: carrier control; Tank 3: 2 ng TBT $\mathrm{l}^{-1}$; Tank 4:8 ng TBT $\mathrm{l}^{-1}$; Tank 5: $32 \mathrm{ng} \mathrm{TBT} \mathrm{l}^{-1}$; Tank 6: $128 \mathrm{ng} \mathrm{TBT} \mathrm{\textrm {l } ^ { - 1 }}$

Tank 1 had a penis at 6 and 9 mo and only in the carrier control (Tank 2) did the percentage remain under $50 \%$ throughout the experiment. However, all the females from the highest dose (128 $\mathrm{ng} \mathrm{l}^{-1}$, Tank 6) had a penis by 3 mo (Fig. 2). A.t 12 mo, all the females exposed to 8,32 and $128 \mathrm{ng} \mathrm{l}^{-1}$ (Tanks 4,5 and 6) had a penis.

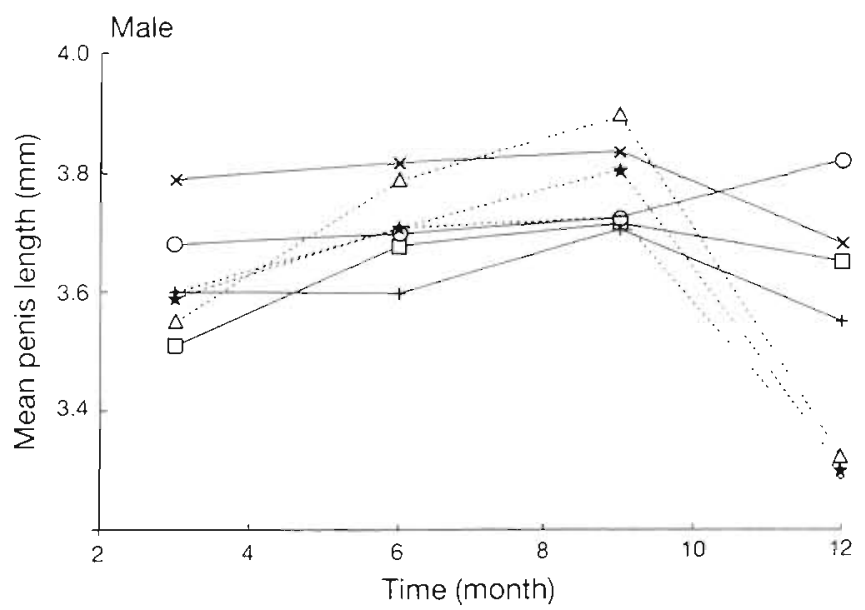

Incidence of imposex

The incidence of imposex (females at vas deferens Stage 2 and above) is presented in Table 5 and Fig. 4 and the percentage of females at each vas deferens stage is shown in Table 5.

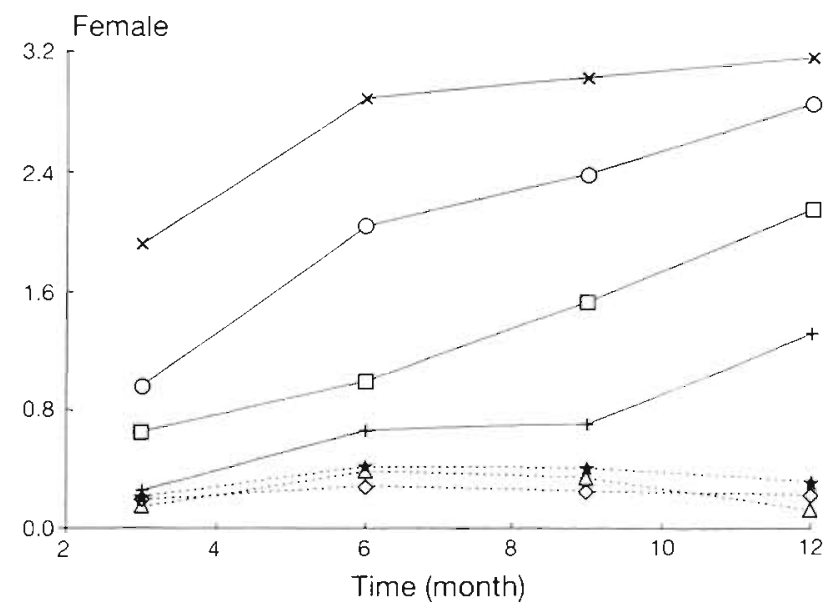

Fig. 3. Nucella lapillus. Mean penis length $(\mathrm{mm})$ in male and female dogwhelks from each treatment tank and a beach sample on each sampling occasion. $(\Delta)$ Beach; $(\star)$ Tank 1, sea water control; $(0)$ Tank 2, carrier control; (+) Tank 3, 2 ng TBT $1^{-1}$; ( $(\square)$ Tank 4,

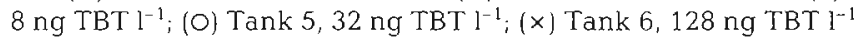


On all sampling occasions, there were significant differences $(p<0.001)$ in imposex occurrence among the treatment Tanks 3 to $6(2,8,32$ and

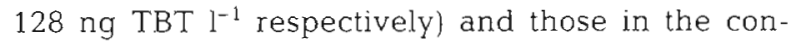
trol Tanks 1 and 2. The incidence of occurrence increased with TBT concentration in the water, and individuals developed imposex earlier in the higher dose treatments. In Tank 3, imposex occurrence after 3 mo was greater $(p<0.05)$ than that in snails from Tank 2, but not different from that in Tank 1. Significant differences ( $p<0.001$ ) were seen between Tank 3 and both control tanks from 6 mo onwards.

The frequency of imposex occurrence in beach samples increased from 0 mo to 9 mo ( $12 \%$ to $70 \%$ ). At 12 mo, however, the frequency decreased to $26 \%$, similar to that recorded at 3 mo.

There were small variations in frequency of imposex occurrence in both control tanks (1 and 2) throughout the year. There was no significant difference between the control tanks for the first 9 mo of the experiment. At $12 \mathrm{mo}$, imposex occurrence fell in both control tanks, but was significantly higher $\left(\chi^{2}=\right.$ 7.99, df $=1, \mathrm{p}<0.01)$ in Tank $1(37 \%)$ than in Tank 2 $(24 \%)$.

At the end of the experiment, imposex occurrence (Table 5) in snails from the beach and the control tanks was greater than that recorded in the prestudy snail sample (12\%). The increases shown by the beach and control snails are comparable to the changes in the level of imposex seen at various locations in Loch Ewe in 1987-90 (Bailey 1991), and do not, therefore, suggest any contamination of the experimental system by the techniques used

There was no indication in the treatment tanks of any reduction in imposex (Table 5) towards the end of the experimental period as observed in the beach and control samples.

\section{Relative Penis Size Index}

Dogwhelks from the beach and control tanks never exhibited an RPSI (Table 5) above 0.15\%. RPSI values in the beach and control Tank 2 increased between 3 and 6 mo and decreased subsequently to values similar to those measured in the pre-study sample. RPSIs of snail samples from Tanks 3 to 6 increased at each sampling period (Fig. 5a) and with the treatment concentration (Fig. 6).

Relationships of the form $y=a e^{b x}$, where $y$ is RPSI and $x$ is $\log _{2}$ (target TBT concentration), were found to adequately describe the data obtained at each sampling time (Fig. 7). An analysis of covariance indicated significant differences existed between the

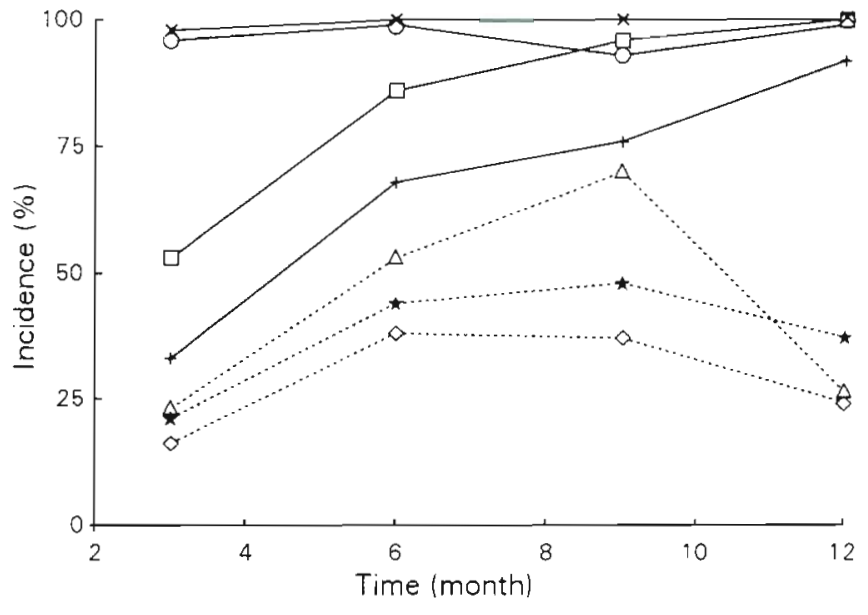

Fig. 4. Nucella lapillus. Incidence of imposex (\%) in female dogwhelks from each treatment tank and a beach sample on each sampling occasion. $(\Delta)$ Beach; $(\star)$ Tank 1 , sea water control; (ᄋ) Tank 2, carrier control; (+) Tank 3, 2 ng TBT l-1 (D) Tank 4,

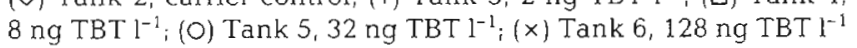
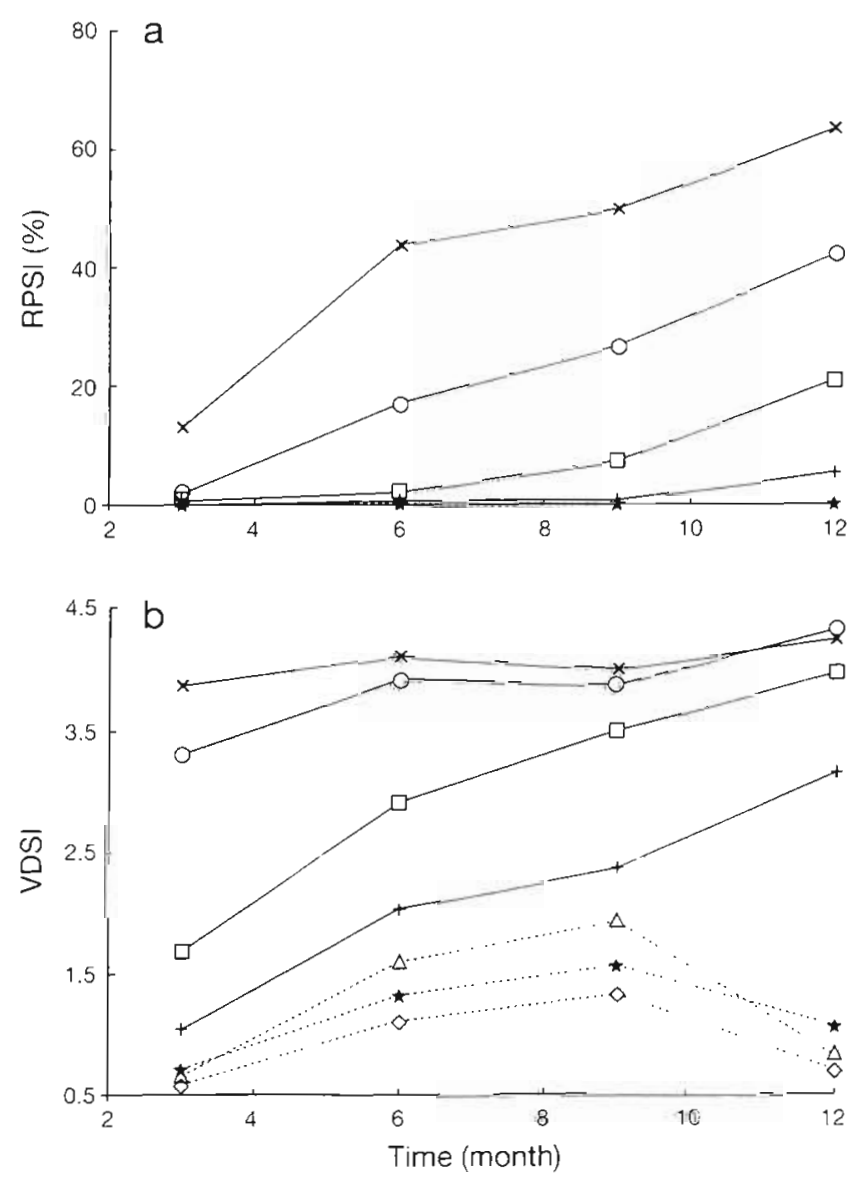

Fig. 5. Nucella lapillus. (a) RPSI (\%) and (b) VDSI of dogwhelks sampled from each treatment tank and a beach sample on each sampling occasion. $(\Delta)$ Beach; $_{*} \star$ ) Tank 1 , sea water controli (ه) Tank 2, carrier control; (+) Tank 3, 2 ng TBT $~^{-1}$; (ㅁ) Tank 4,

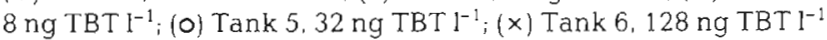




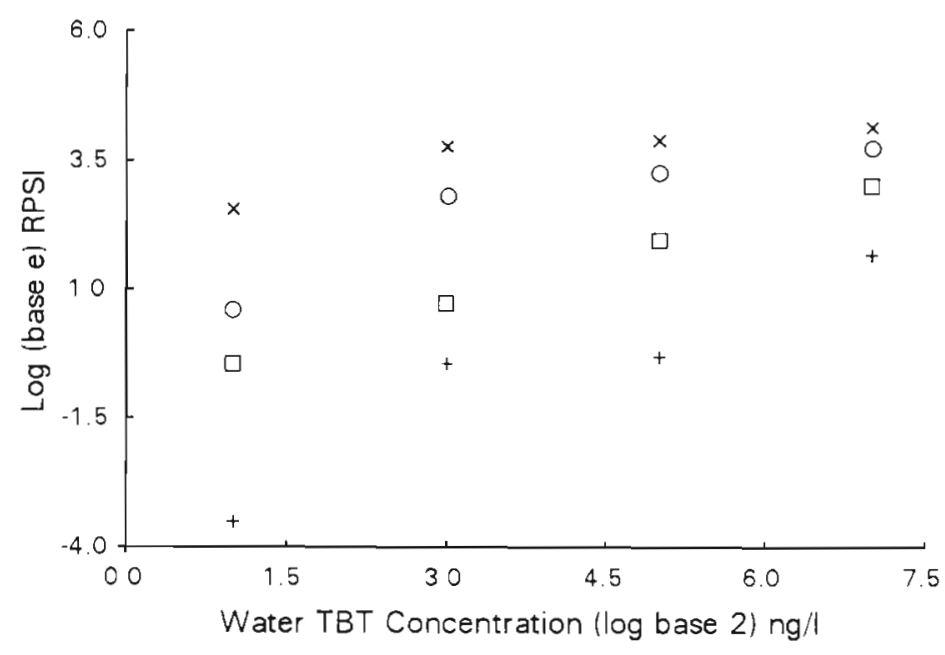

Fig. 6. Relationship between TBT concentration ( $\mathrm{n} \mathrm{l}^{-1}$ ) in water and RPSI (\%) in Nucella lapillus. (+) 3 mo, Nov; (ㅁ) 6 mo, Feb; (O) 9 mo, May; $(x) 12$ mo, Aug

powers $(p<0.05)$ and constants $(p<0.001)$ of these relationships between sampling times, confirming that the period of exposure is important in determining the extent of imposex development. Dogwhelks exposed to $2 \mathrm{ng} \mathrm{TBT} \mathrm{l}^{-1}$ for $12 \mathrm{mo}$, for example, had an RPSI of $5.3 \%$ whereas snails exposed to $8 \mathrm{ng} \mathrm{l}^{-1}$ for 9 mo had an RPSI of only $7.2 \%$.

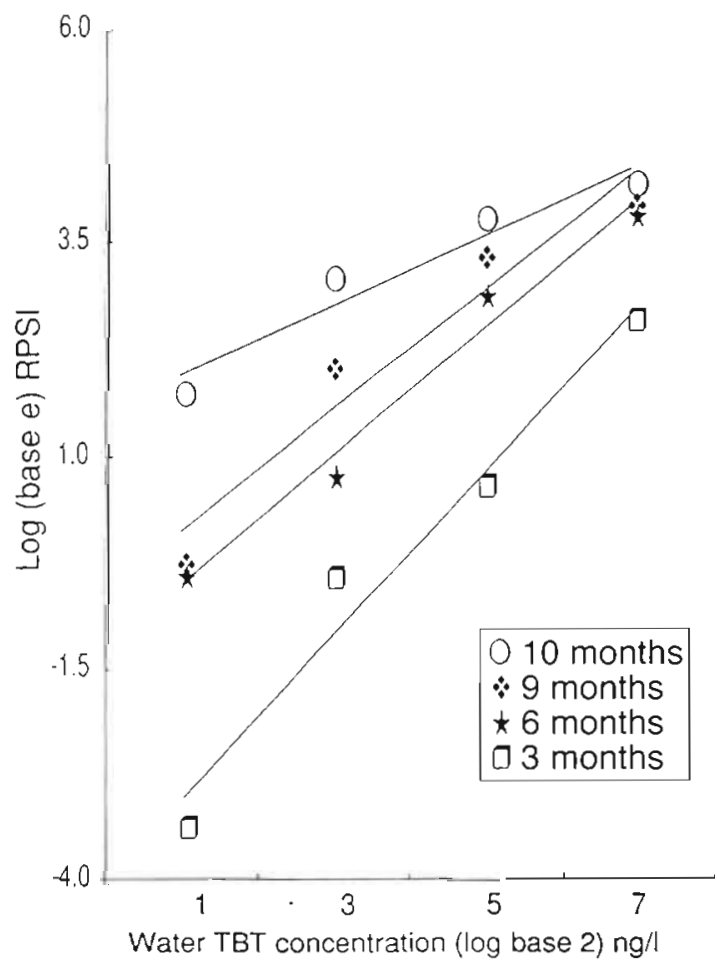

Fig. 7. Fitted relationship $\left(y=a e^{b x}\right)$ between the RPSI in Nucella lapillus and TBT concentration (ng $\left.~^{-1}\right)$ in water
Vas Deferens Sequence Index

The VDSI measured in snails (Table 5) was significantly (analysis of variance) different between tanks $(p<0.001)$ and between sampling occasions $(p<0.01)$. Over all sampling occasions (Fig. 5b), the VDSIs from the 4 TBT treated tanks were significantly greater $(p<0.05)$ than the VDSIs in either the snails from the beach or the control tanks. The VDSIs from the beach and control samples were similar throughout the experiment and all passed through maximum values at 9 mo. The VDSIs measured in all samples during the course of the experiment were greater than the VDSI in the pre-study snail sample (0.34).

At 3 and 6 mo the influence of treatment dose on VDSI development is strong, with VDSI increasing with increasing dose. After 9 and 12 mo exposure, VDSI is high in all treated tanks confirming that, as with RPSI, both TBT concentration and length of exposure are important in VDSI development.

\section{Dogwhelk weight}

Casual observations made during imposex analyses suggested that the experimental snails appeared generally bigger than snails from the shore. Mean weights for each sex from each treatment (Table 6) confirmed that, following the winter period, snails from the beach were consistently lighter (mean weight of males in February $=0.77 \mathrm{~g}$ ) than the experimental snails (e.g. Tank 1 males in February $=0.92 \mathrm{~g}$ ). Over the small size range of dogwhelks used in the experiment, no correlation was found between shell length and body weight.

A 2-way analysis of variance of male weights indicated significant differences between tanks ( $p<0.01)$ and sampling times $(p<0.001)$ and a significant interaction $(p<0.01)$. The interaction was due mainly to the beach samples, and when these were excluded the interaction was not significant. The males tended to be in poorest condition (in terms of body weight) in May, following the winter period and spawning, and in their best condition in August after 12 mo (e.g. Tank 1 mean weight in May $=0.84 \mathrm{~g}$, August $=1.14 \mathrm{~g}$ ).

Similar results were found for females. Significant differences between tanks and sampling times (both $p<0.001$ ) were again found after excluding data for the beach. The data at the end of the experiment indicated that, after a year's exposure to concentrations of $2 \mathrm{ng} \mathrm{l}^{-1}$ and above, the mean weight of females and males was negatively related to the TBT concentration $(p<0.01$ and $p<0.05$ respectively). 
Table 6. Nucella lapillus. Mean weights of male and female dogwhelks from each sampling occasion. Standard errors shown for sampling at 12 mo

\begin{tabular}{|c|c|c|c|c|c|c|c|c|}
\hline \multirow{2}{*}{$\begin{array}{l}\text { Tank TBT } \\
\text { conc. }\left(\text { ng l }^{-1}\right)\end{array}$} & \multicolumn{2}{|c|}{$3 \mathrm{mo}$, Nov } & \multicolumn{2}{|c|}{$6 \mathrm{mo}$, Feb } & \multicolumn{2}{|c|}{9 mo, May } & \multicolumn{2}{|c|}{$12 \mathrm{mo}$, Aug } \\
\hline & Males & Females & Males & Females & Males & Females & Males & Females \\
\hline Beach & 0.96 & 0.96 & 0.77 & 0.78 & 0.71 & 0.72 & $0.72 \pm 0.03$ & $0.74 \pm 0.06$ \\
\hline Control & 0.95 & 1.01 & 0.92 & 0.95 & 0.84 & 1.05 & $1.14 \pm 0.06$ & $1.14 \pm 0.06$ \\
\hline Carrier control & 0.92 & 0.94 & 0.99 & 1.06 & 0.82 & 1.04 & $0.95 \pm 0.04$ & $1.11 \pm 0.06$ \\
\hline 2 & 0.95 & 0.91 & 0.88 & 0.91 & 0.79 & 0.92 & $1.04 \pm 0.05$ & $1.12 \pm 0.01$ \\
\hline 8 & 0.88 & 0.98 & 0.91 & 0.93 & 0.83 & 0.96 & $0.98 \pm 0.03$ & $1.05 \pm 0.03$ \\
\hline 32 & 0.85 & 0.83 & 0.89 & 0.91 & 0.80 & 1.03 & $0.94 \pm 0.03$ & $0.95 \pm 0.01$ \\
\hline 128 & 0.83 & 0.92 & 0.84 & 0.85 & 0.85 & 0.99 & $0.91 \pm 0.02$ & $0.94 \pm 0.05$ \\
\hline
\end{tabular}

Dogwhelk activity

Counts of the number of snails ascending tank walls following dislodgement were made, and the mean activity levels recorded for each month. A 2-way analysis of variance indicated significant differences $(p<0.001)$ in activity of snails both between tanks and months. There was no consistent pattern with treatment level, although Tank 5 individuals frequently showed a low level of activity, whilst individuals from Tanks 2 and 3 were generally more active.

\section{Feeding rate}

Estimates of the weight of mussel flesh consumed per snail were made on 17 occasions between November and August (Table 7 ). There were significant $(\mathrm{p}<0.001)$ differences in the amount of mussel eaten at different times of the year. Feeding rates were lowest between January and April (Table 7), greatest in June and fell again in July and August. The fall in feeding rate in July is consistent with the decline in activity in the snails at this time and is possibly the result of a post breeding inactive phase, as females in all tanks were laying egg capsules during May and June (I.M.D. pers. obs.). Feeding rates and temperature showed a strong positive correlation.

The 2 methods used to calculate feeding rate generally gave similar results. Data obtained by Method 1 showed no significant difference between tanks, but Method 2 indicated differences $(p<0.05)$. This difference is a result of slightly higher feeding rates calculated for Tank 3 using Method 2 (mean food consumption in Tank 3 snails for the entire feeding experiment $=0.20 \mathrm{~g} \mathrm{snail}{ }^{-1} \mathrm{~d}^{-1}$, whereas food consumption for snails in Tanks $1,2,4,5$ and 6 were $0.17,0.16,0.17,0.17$ and $0.17 \mathrm{~g} \mathrm{snail}^{-1} \mathrm{~d}^{-1}$ respectively). Method 1 showed similar patterns, but the magnitude of the differences between tanks obtained by this method was smaller. There was no correlation between food consumption rate and TBT treatment concentration.

There were some indications that changes in the activity of the dogwhelks could be linked with changes in feeding rate, both variables showing low values in July. However, temperature and seasonal variations in

Table 7. Nucella lapillus. Estimation of the food consumption rate of dogwhelks in each tank, as derived by 2 different methods.

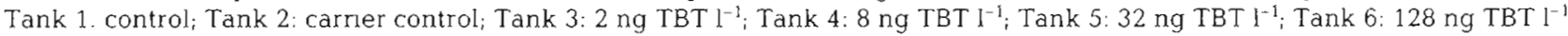

\begin{tabular}{|c|c|c|c|c|c|c|c|c|c|c|c|c|c|c|c|c|c|}
\hline \multirow{2}{*}{ Tank } & \multicolumn{17}{|c|}{ Weight of mussel consumed dogwhelk ${ }^{-1}$ wk $^{-1}(g)$} \\
\hline & 20 Nov & $4 \mathrm{Dec}$ & 19 Dec & $15-16 \mathrm{Jan}$ & $29-30 \mathrm{Jan}$ & 19 Fé & $7 \mathrm{Ma}$ & $21 \mathrm{Mar}$ & 4 Apr & 18 Apr & 2 May & 23 May & 7 Jun & 26 Jun & $16 \mathrm{Jul}$ & 3 Aug & 20-22 Auq \\
\hline \multicolumn{18}{|c|}{ Method 1} \\
\hline 1 & 0.192 & 0.111 & 0.074 & 0.056 & 0.020 & 0.052 & 0.073 & 0.044 & 0.102 & 0.141 & 0.085 & 0.152 & 0.401 & 0.388 & 0.243 & 0.256 & 0.212 \\
\hline 2 & 0.216 & 0.119 & 0.091 & 0.046 & 0.043 & 0.095 & 0.075 & 0.021 & 0.079 & 0155 & 0.040 & 0.132 & 0377 & 0.350 & 0.236 & 0.236 & 0.192 \\
\hline 3 & 0191 & 0.118 & 0.081 & 0.026 & 0044 & 0063 & 0.132 & 0.090 & 0.126 & 0.103 & 0.093 & 0.135 & 0.548 & 0.442 & 0.284 & 0.215 & 0273 \\
\hline 4 & 0.212 & 0.112 & 0.089 & 0.066 & 0.030 & 0.064 & 0.095 & 0.028 & 0.148 & 0113 & 0.087 & 0.175 & 0.403 & 0.326 & 0.204 & 0.214 & 0.221 \\
\hline 5 & 0.187 & 0.147 & 0.039 & 0.047 & 0.031 & 0.019 & 0.072 & 0.023 & 0.089 & 0.163 & 0.109 & 0.214 & 0.387 & 0.342 & 0.173 & 0.270 & 0.233 \\
\hline 6 & 0.137 & 0.144 & 0.028 & 0.041 & 0.013 & 0.053 & 0.062 & 0.041 & 0.144 & 0.106 & 0.140 & 0.157 & 0.398 & 0.279 & 0.220 & 0.188 & 0.292 \\
\hline \multicolumn{18}{|c|}{ Method 2} \\
\hline 1 & - & 0.115 & - & 0.084 & 0.059 & 0.054 & 0.090 & 0.051 & 0.124 & 0.154 & 0.090 & 0164 & 0.377 & 0.396 & 0.232 & 0.230 & 0.267 \\
\hline 2 & - & 0.140 & - & 0.071 & 0.092 & 0.093 & 0.073 & 0.035 & 0100 & 0.153 & 0.075 & 0.139 & 0.364 & 0.351 & 0.231 & 0.219 & 0.233 \\
\hline 3 & - & 0.136 & - & 0.059 & 0.121 & 0.067 & 0.127 & 0106 & $0 \lcm{143}$ & 0130 & 0.108 & 0.149 & 0.507 & 0.450 & 0.279 & 0.250 & 0.323 \\
\hline 4 & - & 0135 & - & 0.088 & 0.079 & 0.062 & 0.122 & 0.034 & 0.201 & 0.118 & 0.097 & 0.176 & 0.386 & 0.361 & 0.218 & 0.218 & 0.252 \\
\hline 5 & - & 0139 & - & 0.071 & 0.074 & 0.034 & 0.066 & 0.035 & $0: 43$ & 0181 & 0.131 & 0.230 & 0.355 & 0.393 & 0.170 & 0.258 & 0.299 \\
\hline 6 & - & 0.153 & - & 0.080 & 0.065 & 0.057 & 0.074 & 0.047 & 0174 & 0.148 & 0140 & 0.184 & 0.401 & 0.308 & 0.215 & 0.191 & 0.353 \\
\hline
\end{tabular}


breeding and other aspects of behaviour also clearly influenced the feeding rate. There was no indication that exposure to TBT prevented or reduced the feeding rate of the experimental populations. The accumulation of TBT by the feed mussels was dependent on exposure period and concentration, and showed little seasonal variation. The uptake of TBT by the dogwhelks from their food was therefore largely controlled by the feeding rate.

\section{TBT concentration in feed mussels}

The rate of accumulation of TBT in mussel tissue was investigated in November (14 d), May (15 d) and August (17 d) (Table 8) and was found to be dependent on the concentration of TBT to which the mussels were exposed. On all occasions, TBT was undetectable in mussels from Tanks 1,2 and 3. TBT concentrations in mussels from Tanks $4\left(8 \mathrm{ng} \mathrm{l}^{-1}\right)$ and $5\left(32 \mathrm{ng} \mathrm{l}^{-1}\right)$ increased slowly throughout the $2 \mathrm{wk}$ feeding period in November, attaining maxima of $0.13 \mathrm{mg} \mathrm{kg}^{-1}$ (Tank $4,14 \mathrm{~d}$ ) and $0.27 \mathrm{mg} \mathrm{kg}^{-1}$ (Tank 5, $11 \mathrm{~d}$ ) respectively. TBT concen-

Table 8. Concentration of TBT ( $\mathrm{mg} \mathrm{kg} \mathrm{kg}^{-1}$ ) in feed mussels Mytilus edulis, including replicate analyses(- denotes sample not analysed). Tanks 1: control; Tank 2: carrier control Tank 3: 2 ng TBT $~^{-1}$; Tank 4: $8 \mathrm{ng}$ TBT I $^{-1}$ i Tank 5: 32 ng TBT $\mathrm{l}^{-1}$ : Tank 6: $128 \mathrm{ng} \mathrm{TBT} \mathrm{l^{-1 }}$

\begin{tabular}{|c|c|c|c|c|c|c|}
\hline \multirow{2}{*}{$\begin{array}{l}\text { Period of mussel } \\
\text { exposure to TBT } \\
\text { treatment (d) }\end{array}$} & \multicolumn{6}{|c|}{ Tank } \\
\hline & 1 & 2 & 3 & 4 & 5 & 6 \\
\hline \multicolumn{7}{|c|}{ Nov (3rd month of dogwhelk exposure) } \\
\hline 2 & $<0.02$ & $<0.02$ & $<0.02$ & 0.03 & 0.09 & 0.26 \\
\hline 4 & - & - & - & $\begin{array}{l}0.04 \\
0.03\end{array}$ & $\begin{array}{l}0.16 \\
0.16\end{array}$ & 0.60 \\
\hline 7 & $<0.02$ & $<0.02$ & $<0.02$ & 0.07 & 0.19 & 0.57 \\
\hline 9 & - & - & $<0.02$ & 0.05 & $\begin{array}{l}0.24 \\
0.24\end{array}$ & 0.81 \\
\hline 11 & - & - & - & 0.07 & 0.27 & $\begin{array}{l}0.96 \\
0.96\end{array}$ \\
\hline 14 & $<0.02$ & $<0.02$ & $\begin{array}{l}<0.02 \\
<0.02 \\
<0.02\end{array}$ & 0.13 & 0.24 & 1.03 \\
\hline \multicolumn{7}{|c|}{ May (9th month of dogwhelk exposure) } \\
\hline 15 & $<0.02$ & $<0.02$ & $<0.02$ & 0.09 & 0.21 & 0.75 \\
\hline \multicolumn{7}{|c|}{ Aug (12th month of dogwhelk exposure) } \\
\hline 3 & $<0.02$ & $<0.02$ & $<0.02$ & $<0.02$ & 0.06 & 0.27 \\
\hline 5 & - & - & - & 0.03 & 0.16 & 0.47 \\
\hline 7 & - & - & - & 0.03 & 0.16 & 0.56 \\
\hline 10 & - & - & - & 0.04 & 0.23 & 1.04 \\
\hline 12 & - & - & - & 0.06 & 0.23 & 0.83 \\
\hline 14 & - & - & - & 0.07 & 0.20 & $\begin{array}{l}0.74 \\
0.57\end{array}$ \\
\hline 17 & $<0.02$ & $<0.02$ & $<0.02$ & 0.10 & 0.26 & 1.11 \\
\hline
\end{tabular}

trations in mussels from Tank 6 increased throughout the feeding period to $1.03 \mathrm{mg} \mathrm{kg} \mathrm{kg}^{-1}$ after $14 \mathrm{~d}$ in November. Time-weighted mean TBT concentration in the mussels in each treatment dose were estimated as 0.07,0.20 and $0.69 \mathrm{mg} \mathrm{kg}^{-1}$ in Tanks 4 to 6 repectively.

\section{DISCUSSION}

The general biological observations regarding mortality, size, food consumption and general level of activity were not found to be related to TBT exposure. Mortalities of dogwhelks in treatment and control tanks were low $(<10.0 \%)$, and not inconsistent with estimated maximum mortalities of wild dogwhelks of ages 5 to 8 yr. Exposure to relatively high concentrations of TBT up to $128 \mathrm{ng} \mathrm{l}^{-1}$ did not result in acute toxicity, in agreement with the findings of Gibbs et al. (1988). It is thought that the loss of wild dogwhelk populations in areas heavily impacted by TBT is the result of suppression of oogenesis (Bryan et al. 1986, Bailey \& Davies 1989), the inhibition of egg capsule deposition by females and rupturing of females through the accumulation of unlaid egg capsules (VDSI Stage 6) (Gibbs et al. 1987). No females in the tanks attained VDSI Stage 6, and so mortalities from this mechanism did not occur.

The greater body weights of dogwhelks in all tanks compared to the source wild population may be a reflection of the relatively protected conditions in the tanks, and the lack of any limitation of food availability. The body weight of male dogwhelks showed marked seasonal variation ( $p<0.01$ ), and an indication of negative correlation with concentration. In addition, the body weight of females after 12 mo exposure was also negatively correlated with exposure concentration $(p<0.01$ ). While control females and males were 52 and $45 \%$ heavier, respectively, than beach samples, Tank 6 females and males were only 27 and $26 \%$ heavier respectively. It is possible that the reduced weight of exposed snails may be reflected in reduced reproductive capacity, even at VDSI values less than 5.

The general level of activity of the dogwhelks was not consistently related to TBT exposure, but was greatest in May, when the mean water temperature increased above $9^{\circ} \mathrm{C}$. Variation in the activity of the snails with time may in part be explained by the increase in water temperature during the spring period. However, a more important factor is likely to be the normal seasonal pattern of behaviour exhibited by dogwhelks in the wild (Crothers 1985). During October, dogwhelks normally form winter aggregations to minimise the possibility of dislodgement during bad weather. Similar aggregations are formed in the spring, prior to breeding. At both of these times, dogwhelks cease feeding and be- 
come relatively inactive (Crothers 1985). This seasonal behaviour is consistent with the observations made during this experiment, whereby dogwhelk activity was low between October and May and increased during the summer period.

Mean bioconcentration factors (BCFs; ratio of TBT concentrations in soft tissues to water on a wet weight basis) for fed dogwhelks were 25000, 21200,17500 and 7400 for individuals in treatment concentrations $2,8,32$ and $128 \mathrm{ng} \mathrm{l}^{-1}$ respectively. Mussels from Tanks 4 to 6 bioconcentrated TBT by smaller factors $(8800,6300$ and 3900 respectively). The bioconcentration factors of TBT in both the snails and mussels decreased as the water concentration increased. Although the mussels were exposed to $30000 \mathrm{l}$ of treated water over each $2 \mathrm{wk}$ period, concentrations of TBT in mussel tissue may not have attained equilibrium, and BCFs may be underestimated.

Tissue concentrations of TBT in the snails were higher than those found in the mussels, indicating an accumulation of TBI within the food pathway. Concentrations of TBT were approximately twice as high in snails as in mussels maintained at each treatment dose, indicating that the diet accounted for approximately $40 \%$ of the TBT within the dogwhelks. In a similar experiment (Bryan et al, 1989), dogwhelks exposed to a nominal concentration of $30 \mathrm{ng} \mathrm{TBT}^{-1}$

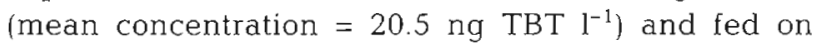
mussels exposed to the same concentration showed a bioconcentration factor of approximately 18000 after $49 \mathrm{~d}$ exposure. Approximately $50 \%$ of the TBT in the snails was accounted for by uptake from the mussels.

The mean penis lengths in males from the 4 treated tanks were greater than those in males from the beach and 2 control tanks at the end of the experiment. Previous investigations have shown that penis growth in males in field populations can be stimulated by the presence of TBT (Bailey \& Davies 1991). The decrease in penis length in males from the beach and the controls between May and August may reflect a seasonal cycle of penis size changes, for example, penes being larger during the breeding period. A similar decrease in male penis length was found by Oehlmann et al. (1991) in field samples and by Ritsema et al. (1991) in transplanted dogwhelks. The presence of only $2 \mathrm{ng}$ $\mathrm{TBT}^{-1}$ in the water appears however to override such seasonal length changes.

A low degree of imposex (RPSI and VDSI) was found in the pre-study female snails at an incidence of $12 \%$. This may either reflect a natural, background level of this phenomenon found in populations which is unrelated to pollution from chemical substances and possibly related to the exposed aspect of the sampling site (Oehlmann et al. 1991), or indicate that the snails have previously been exposed to some substance that has caused the onset of imposex development. Dogwhelks from the same area 3 Yr earlier had an RPSI of $0.00 \%$ and a VDSI of 0.70 (Bailey \& Davies 1989). This suggests either that the snails were 'contaminated' before this time and that the cause of contamination ceased so that the imposex condition of the snails did not worsen, or that the snails exhibit a 'natural' level of pseudohermaphrodism (Bryan et al. 1986). Other factors, however, such as copper, paint matrix and environmental stress, have been found to induce imposex in the gastropod Lepsiella vinosa (Nias et al. 1993)

If the results of the beach and control tank data are combined, the frequencies of imposex occurrence in the pre-study snails and the quarterly samples were $12,20,45,52$ and $29 \%$ respectively. The incidence of imposex appears to follow a seasonal pattern, being highest in the spring, when the females are sexually active (Crothers 1985), and lowest in the summer and winter. Penis lengths in females and RPSI and VDSI values all showed a similar pattern, supporting the suggestion of a seasonal flux, probably linked to the reproductive cycle. However, the pattern did not occur at TBT concentrations of $2 \mathrm{ng} \mathrm{l}^{-1}$ or more, and has only been demonstrated at rather low levels of imposex (RPSI $<0.2 \%$ ). It may be concluded that imposex at these levels may, to some extent, be reversible.

The mean penis lengths in females from the treated tanks (2 to $128 \mathrm{ng} \mathrm{l}^{-1}$ TBT dosage) were greater than those in the controls on all sampling occasions, and increased with both concentration and exposure period. Significant differences $(p<0.001)$ in penis development were seen between snails from the control tanks 11 and 2) and snails from Tanks 4 to 6 after 3 mo exposure, and after 6 mo in Tank 3 ( $2 \mathrm{ng} \mathrm{TBT}^{-1}$ ). A concentration of $2 \mathrm{ng} \mathrm{TBT}^{-1}$ in water (the lowest concentration tested) is therefore clearly sufficient to promote imposex development. Gibbset al. (1988) showed that dogwhelks with VDSI of less than 4 in water containing less than $0.5 \mathrm{ng}$ tin $\mathrm{l}^{-1}$ were able to breed normally. Concentrations of 2 to $20 \mathrm{ng}$ tin $\mathrm{l}^{-1}$ in waters from southwest England have been shown (Gibbs et al. 1987) to result in VDSI values of 5 and 6 , indicating sterility in these females.

A no-observed-effect concentration (NOEC) is the highest concentration in which effects are not different from controls. The incidence of imposex $(12 \%)$, RPSI $(0.01 \%)$ and VDSI $(0.34)$ in snails analysed at the start of the current investigation indicated that a number of snails used to stock each of the treatment tanks already possessed a small penis and/or a vas deferens.

The RPSI of the pre-study dogwhelk sample is similar to that obtained from the beach and control Tank 2 samples taken in August (12 mo sample). The VDSIs of the August samples were all higher than the VDSI of the pre-study sample. The mean penis size, incidence of imposex, RPSI and VDSI of the dogwhelks exposed 
to $2 \mathrm{ng}$ TBT $\mathrm{l}^{-1}$ (the lowest treatment level) are all greater than those values obtained from the control tanks. It may therefore be concluded that the NOEC is less than $2 \mathrm{ng} \mathrm{TBT} \mathrm{l}^{-1}$. Reliable experimentation at concentrations below this is presently difficult, and clear establishment of a NOEC would require significant improvements in chemical analysis and tank maintenance techniques.

The data from the current rigorously controlled experiment can be compared to previous data. Bryan et al. (1987) studied the effects of antifouling paints containing TBT (as leachates) on Nucella lapillus in laboratory experiments with a similar approach of using simulated tidal tank exposures over a period of up to $14 \mathrm{mo}$. In the control sets, where TBT concentrations were approximately $4 \mathrm{ng} 1^{-1}$, all snails showed imposex to significant degree. In the treatment groups, where TBT concentrations (from the paint leachates) were measured at approximately 9,47 and $268 \mathrm{ng} \mathrm{l}^{-1}$, the degree of imposex was higher than in the controls.

In a further publication, Gibbs et al. (1988) reported imposex data for Nucella lapillus after 24 mo exposure of juvenile to adult stages to leachates of an antifouling paint containing TBT. The controls lobtained from the same site as the treated snails, and not held under laboratory conditions) contained TBT concentrations of 3 to $5 \mathrm{ng} \mathrm{l}^{-1}$, and exposure groups had measured concentrations of approximately 10,50 and $250 \mathrm{ng} \mathrm{l}^{-1}$ The number of females evaluated was small (10 to 15 per treatment group). The degree of imposex was less in the field controls compared to the treatment groups. However, no concentration dependence could be evaluated as the females showed very similar degrees of imposex, and most of them were reported to be sterile. Overall the precise involvement of TBT in inducing or promoting imposex was difficult to determine.

The results of our study support the earlier data indicating that low concentrations of below $2 \mathrm{ng} \mathrm{l}^{-1}$ promote the development of imposex in Nucella lapillus. Unlike the earlier reports, however, it was found that there was a seasonally varying baseline level of imposex in uncontaminated populations, indicating either that environmental stressors other than TBT induced imposex (as was found by Nias et al. (1993) for another gastropodl or that a certain percentage of imposex can be a natural phenomenon for dogwhelk populations. The degree of imposex was different from the 2 laboratory studies cited above. Even the exposure to TBT concentrations of $128 \mathrm{ng} \mathrm{l}^{-1}$ over 12 mo in the present study did not lead to sterility in the females. Factors such as the previous exposure of TBT, the condition of the test snails, age during exposure, and perhaps regional differences in populations may contribute to the expression of imposex in $N$. lapillus. Oehlmann et al. (1991) indicated that populations may be geneti- cally different, possibly resulting in slight differences in the expression of imposex.

These findings may reflect the difficulties encountered when extrapolating the laboratory experiments to field observations. Many reports have been published on imposex in Nucella lapillus in the environment and its use as an indicator for TBT contamination (e.g. Davies et al. 1987, Gibbs et al. 1987, Minchin et al. 1995). While there is little controversy about a correlation of high degrees of imposex in $N$. lapillus and elevated concentrations of TBT in the coastal environment, the discussion of the results of this study and previous investigations showed considerable uncertainty about the association of lower degrees of imposex and TBT contamination.

In terms of the ecological relevance of imposex in Nucella lapillus, the literature does not give a clear picture. Gibbs et al. (1987) and data from the Quality Status Report of the North Sea (Anon 1993) reported the decrease of dogwhelk populations around South England due to the high number of sterile females. Evans et al. (1996) found healthy populations of dogwhelks in many places around the North Sea coastline, sometimes in populations which were previously reported to contain large numbers of sterile females.

The mechanism by which TBT exposure may lead to effects in dogwhelks at the population level is through inhibition of reproduction, particularly egg production, hatching and survival and development of juveniles, and will be reported elsewhere.

\section{CONCLUSIONS}

Experiments conforming to GLP standards confirm that:

(1) The activity (mobility) of dogwhelks, and their feeding rate, were not affected by exposure to TBT concentrations up to $128 \mathrm{ng} \mathrm{l^{-1 }}$.

(2) After 12 mo exposure, the weight of female and male dogwhelks was negatively correlated with TBT exposure concentration.

(3) Mean TBT bioconcentration factors (water to dogwhelks) ranged from 7400 to 25000 , and decreased with increasing TBT exposure concentration.

(4) Male penis lengths showed small seasonal variations, which were overridden by exposure to a concentration of $2 \mathrm{ng} \mathrm{TBT} \mathrm{l}^{-1}$

(5) Female dogwhelks showed seasonal variations in occurrence of low imposex (RPSI $<0.2 \%$ ), penis length and VDSI. Low levels of imposex were to some extent reversible, but the seasonal cycle was overridden by exposure to concentrations of TBT of $2 \mathrm{ng} \mathrm{l}^{-1}$ or more.

(6) TBT promoted imposex development in Nucella lapillus. The NOEC was less than $2 \mathrm{ng} \mathrm{l}^{-1}$. 
Acknowledgements. This work was funded by the Organotin Environmental Programme Association, to which the authors extend their thanks. The authors also thank Drs G. Rodger and $\mathrm{G}$. Topping for advice on the preparation of the manuscript.

\section{LITERATURE CITED}

Anon (1993) North Sea Quality Status Report. Oslo and Paris Commissions, London

Bailey SK (1991) Tributyltin (TBT) contamination in Scottish coastal waters. PhD thesis, Napier University, Edinburgh

Bailey SK, Davies IM (1989) The effects of tributyltin on dogwhelks (Nucella lapillus) from Scottish coastal waters. J Mar Biol Assoc UK 69:335--354

Bailey SK, Davies IM (1991) The continuing impact of TBT used in mariculture on dogwhelk (Nucella lapillus L.) populations in a Scottish sea loch. Mar Environ Res 32: $187-200$

Bryan GW, Gibbs PE, Burt GR, Hummerstone LG (1987) The effects of tributyltin (TBT) accumulation on adult dogwhelks, Nucella lapillus: long-term field and laboratory experiments. J Mar Biol Assoc UK 67:525-544

Bryan GW, Gibbs PE, Hummerstone LG, Burt GR (1986) The decline of the gastropod Nucella lapillus around southwest England: evidence for the effects of tributyltin from antifouling paints. J Mar Biol Assoc UK 66:611-640

Bryan GW. Gibbs PE, Hummerstone LG, Burt GR (1989) Uptake and transformation of ${ }^{14} \mathrm{C}$-labelled tributyltin chloride by the dog-whelk, Nucella lapillus: importance of absorption from the diet. Mar Environ Res 28:241-245

Crothers JH (1985) Dogwhelks: an introduction to the biology of Nucella lapillus (L.). Field Stud 6:291-360

Davies IM, Bailey SK (1991) The impact of tributyltin from large vessels on dogwhelk (Nucella lapillus) populations around Scottish oil ports. Mar Environ Res 32:201-212

Davies IM, Bailey SK, Moore DC (1987) Tributyltin in Scottish sea lochs, as indicated by degree of imposex in the dogwhelk, Nucella lapillus (L.). Mar Pollut Bull 18:400-404

Department of Health (1989) Good laboratory practice. The United Kingdom compliance Programme. Department of Health, London

Dowson PH, Bubb JM, Lester JN (1993) Temporal distribution of organotins in the aquatic environment: five years after the 1987 UK retail ban on TBT based antifouling paints. Mar Pollut Bull 26(9):487

Editorial responsibility: Otto Kinne (Editor), Oldendorf/Luhe, Germany
Evans SM, Evans PM, Leksono I (1996) Widespread recovery of dogwhelks, Nucella lapillus (L.), from tributyltin contamination in the North Sea and Clyde Sea Mar Pollut Bull 32(3):263-269

Gibbs PE. Bryan GW, Pascoe PL, Burt GR (1987) The use of the dogwhelk Nucella lapillus, as an indicator of tributyltin (TBT) contamination. J Mar Biol Assoc UK 67 $507-523$

Gibbs PE, Pascoe PL, Burt GR (1988) Sex change in the female dogwhelk, Nucella lapillus, induced by tributyltin from anti-fouling paints. J Mar Biol Assoc UK 68:715-731

Harding MJC, Bailey SK, Davies IM (1992) TBT imposex survey of the North Sea. Contract PECD 7/8/214. Scottish Fisheries Working Paper, 9/92. UK Department of the Environment, London

Langston WJ, Pope ND (1995) Determinants of TBT adsorption and desorption in estuarine sediments. Mar Pollut Bull 31(1-3):32-43

Law RJ, Waldock MJ, Allchin CR, Laslett RE, Bailey KJ (1994) Contaminants in seawater around England and Wales: results from monitoring surveys, 1990-1992. Mar Pollut Bull 28(1 1):668-675

McKie JC (1987) Determination of total tin and tributyl tin in marine biological materials by electrothermal atomic absorption spectrometry. Anal Chim Acta 197:303-308

Minchin D, Ehlmann JO, Duggan CB, Stroben E (1995) Marine TBT antifouling contamination in Ireland, following legislation in 1987. Mar Pollut Bull 30(10):633-639

Nias DJ, McKillup SC, Edyvane KS (1993) Imposex in Lepsiella vinosa from Southern Australia. Mar Pollut Bull 26(7):380-384

Oehlmann J, Stroben E, Fioroni P (1991) The morphological expression of imposex in Nueclla lapillus (Linnaeus) (Gastropoda: Muricidae). J Mollusc Stud 57:375-390

Ritsema R, Laane RWPM, Donard OFX (1991) Butyltins in marine waters of the Netherlands in 1988 and 1989 ; concentrations and effects. Mar Environ Res 32:243-260

Spooner N, Gibbs PE, Bryan GW, Goad LJ (1991) The effect of tributyltin (TBT) upon steroid levels in the female dogwhelk, Nucella lapillus, leading to the development of imposex. Mar Environ Res 32(1-4):37-49

Tukey JW (1977) Exploratory data analysis. Addison-Wesley Publishing Company, Reading, MA.

Water Research Centre (1988) Proposed environmental quality standards for List II substances: organotins. WRC Tech Rep TR 255

Submitted: July 18, 1996; Accepted: August 22, 1997 Proofs received from author(s): October 27, 1997 